\title{
IDENTIFICATION OF MYCOBACTERIUM BOVIS ISOLATES BY A MULTIPLEX PCR
}

\author{
Eduardo Eustáquio de Souza Figueiredo ${ }^{1,3}$; Flávia Galindo Silvestre ${ }^{3}$; Wilma Neres Campos ${ }^{3}$; \\ Leone Vinícius Furlanetto ${ }^{3}$; Luciana Medeiros ${ }^{2}$; Walter Lilenbaum ${ }^{2}$; Leila Sousa Fonseca ${ }^{1}$; Joab Trajano Silva ${ }^{1}$; \\ Vânia Margaret Flosi Paschoalin ${ }^{1 *}$
}

${ }^{1}$ Universidade Federal do Rio de Janeiro, Rio de Janeiro, RJ, Brasil; ${ }^{2}$ Universidade Federal Fluminense, Niterói, RJ, Brasil; ${ }^{3}$ Universidade de Cuiabá, Cuiabá, MT, Brasil.

Submitted: March 26, 2008; Returned to authors for corrections: April 30, 2008; Approved: February 15, 2009.

\section{SHORT COMMUNICATION}

\begin{abstract}
Isolates from suggestive bovine tuberculosis lesions were tested by a multiplex polymerase chain reaction (m-PCR) targeting for RvD1Rv2031c and IS6110 sequences, specific for M. bovis and Mycobacterium tuberculosis complex respectively. The m-PCR successfully identified as M. bovis $88.24 \%$ of the isolates.
\end{abstract}

Key words: Mycobacterium bovis, multiplex-PCR, bovine tuberculosis

Several PCR systems have been developed for the detection of species belonging to the M. tuberculosis complex (MTC). The most commonly used one is based on primers that amplify segments of the IS6110 element, particularly targeting for the $123 \mathrm{bp}$ (2) and $245 \mathrm{bp}$ fragments (7). Another PCR system that yield successful identification of $M$. bovis isolates is focused on the amplification of a 500-bp DNA fragment inside the RvD1Rv2031c genomic sequence (4).

A combination of conventional culture and biochemical techniques is the gold standard method currently used for the identification of $M$. bovis, which is laborious and timeconsuming. In this study we carry out the molecular identification of pure cultures of acid-fast bacilli (AFB) isolated from suggestive bovine tuberculosis lesions. The molecular assay consists of a single-step multiplex PCR (m-PCR), based on two set primers already tested that yet to date have not been combined in a single PCR system. In this study, the assay targets simultaneously the RvD1Rv2031c and IS6110 sequences, aiming to identify bacteria as MTC members as well as to distinguish M. bovis isolates from other members of this complex.

A dairy herd from Macaé City (Rio de Janeiro State, Brazil), with a previous history of bovine tuberculosis (TB) was studied. Among the 50 adult cows from this herd tested by intradermal tuberculin test according to official standards (1), 34 animals were reactive, euthanized and necropsied. During the necropsy, a total of 91 samples of lymph nodes and lungs were collected, although not all the animals presented typical lesions. Samples were transported under refrigeration to the Mycobacteriology Laboratory (Universidade Federal do Rio de Janeiro) and tissues of each animal were processed together as one pooled sample per animal, totaling 34 samples. Samples were decontaminated using the Petroff method, inoculated on slopes of LowensteinJensen medium with sodium pyruvate and incubated for three months at $37^{\circ} \mathrm{C}$. After growth, AFB-positive colonies were screened by m-PCR. Briefly, the mycobacterial DNA was extracted as described previously (3). m-PCR was performed in a reaction mix $(50 \mu \mathrm{L})$ containing $5 \mu \mathrm{l}$ of $10 \times$ PCR buffer ((Invitrogen $\left.{ }^{\circledR}\right), 200 \mu \mathrm{M}$ dNTP (GE Healthcare $\left.{ }^{\circledR}\right), 2.5 \mathrm{U}$ of recombinant $T a q$ polymerase (Invitrogen ${ }^{\circledR}$ ), $0.2 \mu \mathrm{M}$ of each primer (Invitrogen ${ }^{\circledR}$ ) JB21 (5'-TCGTCCGCTGATGCAAGTGC$3^{\prime}$ ) and JB22 (5'-CGTCCGCTGACCTC AAGAAAG-3') (4) and INS1 (5'-CGTGAGGGCATCGAGGTGGC-3') and INS2 (5'GCGTAGGCGTCGGTGACAAA-3') (10), $2.0 \mathrm{mM} \mathrm{MgCl}_{2}$, and $5 \mu \mathrm{L}$ of purified DNA template. Amplification was carried out in a GeneAmp PCR System 9600 (Applied Biosystems ${ }^{\circledR}$ ) with the following cycling parameters: $94^{\circ} \mathrm{C}$ for $5 \mathrm{~min}$, followed by 30

*Corresponding Author. Mailing address: Universidade Federal do Rio de Janeiro, Rio de Janeiro, RJ, Brasil. Tel.: $55212562-7362$; Fax: 55 21 2562-7266. E-mail: paschv@iq.ufrj.br 
cycles of $1 \mathrm{~min}$ at $94^{\circ} \mathrm{C}, 1 \mathrm{~min}$ at $68^{\circ} \mathrm{C}$ and $1 \mathrm{~min}$ at $72^{\circ} \mathrm{C}$, with a final extension at $72^{\circ} \mathrm{C}$ for $7 \mathrm{~min}$. PCR products were checked by electrophoresis on $1.5 \%$ agarose gels stained with ethidium bromide $(10 \mu \mathrm{g} / \mathrm{mL})$. Negative samples were analyzed by PCRrestriction analysis (PRA), using primers Tb11 (5'-ACCAA CGATGGTGTGTCCA T-3') and Tb12 (5'-CTTGTCGAACC GCATACCCT-3') targeting for the $h s p 65$ gene (6). The amplification products were digested with BstE II and HaeIII and the resulting fragments were fractionated by agarose gel electrophoresis and stained with ethidium bromide.

Mycobacteria colonies were isolated in Lowenstein-Jensen medium with sodium pyruvate from 17 out 34 (50\%) processed samples, therefore confirming the infection. This herd was TBfree in the last testing, performed six months before the study. Therefore, we believe that the reactive cows presented a recent infection, where visible lesions are not always present and the bacterial load is low. Considering the employed decontamination method, it is not surprising that not all cultures yielded M.bovis. Nevertheless, it is noteworthy to observe that the presence of some positive cultures is sufficient to characterize the outbreak of TB in this herd.

In those 17 isolates, $\mathrm{m}$-PCR successfully amplified both target regions (the $500 \mathrm{bp}$ fragment specific for M. bovis and the 245 bp fragment diagnostic for MTBC) in 15 of them (88.24\%) (Fig. 1, lanes 1-15). The two (11.76\%) m-PCR-negative isolates (Fig. 1 , lanes 16 and 17) were confirmed by PCR-restricition analysis as Mycobacterium sp, but not included into Mycobacterium tuberculosis complex (results not shown).

PCR using primers JB21/JB22 has been considered to be highly reliable in identifying $M$. bovis isolates, presenting $100 \%$ concordance with the conventional microbiological method (4). However, the absolute specificity of JB21/JB22 primers to $M$. bovis has been disputed by other study that reported that $13.3 \%$ (4/30) of $M$. bovis isolates failed to produce the 500bp fragment (5). Using specific primers for IS6110 sequence, the $500 \mathrm{bp}-$ negatives isolates were identified as belonged to the MTC leading the authors to suggest that those isolates may lack the genomic target for JB21/JB22 primes. As this genotypic characteristic may not be so infrequent, the use of a single primer pair can produce false negative results. On the other hand, an additional primer pair targeting for a different sequence, as in $\mathrm{m}$ PCR, minimizes the occurrence of such false negative results.

In the present study, we used two set of primers already described in the literature $(4,10)$ therefore, for the first time, they were combined to optimize a mPCR assay able to identify unequivocally $M$. bovis among mycobacterial isolates. The mPCR method is fast, reproducible and useful for the study of slow-growing mycobacteria, particularly in cultures where the small number of bacilli hinders identification by classical methods. It also can be a valuable tool for the rapid identification of acid-fast bacilli isolated from suggestive bovine TB lesions.

\section{ACKNOWLEDGEMENTS}

The authors want to acknowledge the financial support from FAPERJ, FAPEMAT, CAPES and CNPq.

\section{RESUMO}

\section{Identificação de colônias isoladas de Mycobacterium bovis por PCR múltipla}

Colônias isoladas a partir de lesões sugestivas de tuberculose bovina foram testadas pela reação múltipla em cadeia da polimerase, usando oligonucleotídeos direcionados para as sequiências genômicas RvD1Rv2031c e IS6110, específicas para M. bovis e para o complexo Mycobacterium tuberculosis, respectivamente. A m-PCR identificou, com sucesso, 88,24\% das colônias isoladas como M. bovis.

Palavras-chave: Mycobacterium bovis, PCR-múltipla, tuberculose bovina

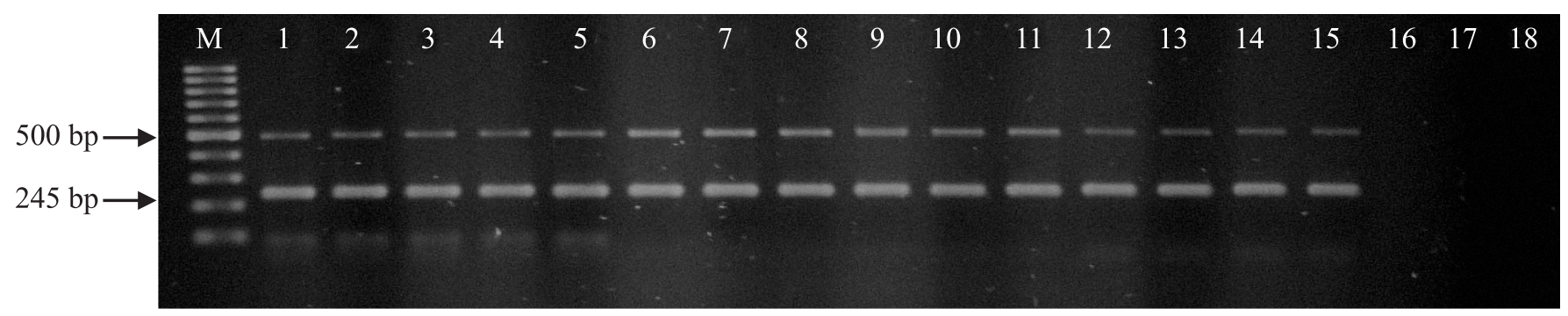

Figure 1. Identification of ABF isolates by m-PCR. DNA extracted from seventeen different acid-fast bacilli isolates was used as template for m-PCR amplification of the RvD1Rv2031c and the IS6110 sequences. Amplification products were separated by electrophoresis on $1.5 \%$ agarose gel and stained with ethidium bromide $(10 \mu \mathrm{g} / \mathrm{mL})$. Lane M: 100 bp DNA ladder (Fermentas $\left.{ }^{\circledR}\right)$; lanes 1-17 m-PCR products of acid-fast bacilli isolated from suggestive BT lesions; lane 18 negative control. Arrows indicate the position of the fragments of $500 \mathrm{bp}$ (diagnostic for M. bovis) and $245 \mathrm{bp}$ (diagnostic for MTBC members). 


\section{REFERENCES}

1. Brasil. (2004). Ministério da Agricultura, Pecuária e Abastecimento. Regulamento Técnico do Programa Nacional de Controle e Erradicação da Brucelose e Tuberculose, Instrução normativa SDA.

2. Eisenach, K.D.; Cave, M.D.; Bates, J.H.; Crawford, J.T. (1990). Polymerase chain reaction amplification of a repetitive DNA sequence specific for Mycobacterium tuberculosis. J. Infect. Dis., 161: $977-81$.

3. Meikle, V.; Scneider, M.; Azenzo, G.; Zumárraga, M.; Magnano, G.; Cataldi, A. (2007). Individual animals of a cattle herd infect with the same Mycobacterium bovis genotype shows important variations in bacteriological, histophathological and immune response parameters. Zoonoses Public Health, 54: 86-93.

4. Rodríguez, J.G.; Fissanoti, J.C.; Del Portillo, P.; Patarroyo, M.E.; Romano, M.I.; Cataldi, A. (1999). Amplification of a 500-basepair fragment from cultured isolates of Mycobacterium bovis. Eur. J. Clin. Microbiol. Infect. Dis., 37: 2330-2332.

5. Sechi, L.A.; Dupre, I.; Leori, G.; Fadda, G.; Zanetti, S. (2000) Distribution of a specific 500-base-pair fragment in Mycobacterium bovis isolates from Sardinian cattle. J. Clin. Microbiol., 38: 3837 3839.

6. Telenti, A.; Marchesi, F.; Balz, M.; Bally, F.; Bottger, E.C.; Bodmer T. (1993). Rapid identification of mycobacteria to the species level by polymerase chain reaction and restriction enzyme analysis. $J$. Clin Microbiol., 31: 175-178.

7. Hermans, P.W.; Van Soolingen, D.; Dale, J.W.; Schuitema, A.R.; Mcadam, R A.; Catty, D.; Van Embden, J.D. (1990). Insertion element IS986 from Mycobacterium tuberculosis: a useful tool for diagnosis and epidemiology of tuberculosis. J. Clin Microbiol., 28: 2051-2058. 